\title{
Combined effect of salinomycin and feeding on whole body glucose kinetics in sheep fed a high-concentrate diet
}

\author{
Tadahisa FuJITA, Hiroya MAJIMA, Takahiro ITOH, Hiroaki SANO* \\ Department of Agro-bioscience, Faculty of Agriculture, Iwate University, Ueda 3-18-8, \\ Morioka 020-8550, Japan
}

(Received 18 February 2006; accepted 9 June 2006)

\begin{abstract}
The aim of this study was to investigate the effects of salinomycin (SL) and feeding on whole body glucose kinetics in sheep fed a high-concentrate diet (25\% orchardgrass hay and $75 \%$ commercial concentrate). Four adult sheep were fed the diet with or without $20 \mathrm{mg} \cdot \mathrm{kg}^{-1}$ diet of SL once daily for each $3 \mathrm{wk}$. The rates of glucose entry and utilization were determined before and during $3 \mathrm{~h}$ after feeding using a $\left[{ }^{13} \mathrm{C}_{6}\right]$ glucose dilution approach. Ruminal characteristics and concentrations of blood volatile fatty acids (VFA) and plasma glucose and insulin were also measured. Metabolizable energy intake was unaffected $(P=0.22)$ with SL. Salinomycin decreased $(P=0.06)$ the ratio of acetate to propionate in rumen fluid. Salinomycin increased $(P=0.01)$ both rates of entry and utilization of glucose, but did not affect $(P>0.10)$ concentrations of blood VFA or plasma glucose or insulin. Feeding caused gradual increases in concentrations of blood acetate $(P<0.01)$ and propionate $(P=0.01)$, a transient increase in plasma insulin concentration $(P=0.05)$, a transient decrease in plasma glucose concentration $(P<0.01)$, and persistent increases in both rates of glucose entry $(P<0.01)$ and utilization $(P<0.01)$. No SL $\times$ feeding interaction was observed $(P>0.10)$ on any measurements. We conclude that SL and feeding would have an additive effect on both rates of glucose entry and utilization without modifications with SL to feeding responses of peripheral concentrations of blood VFA, plasma glucose and insulin.
\end{abstract}

feeding / glucose metabolism / insulin / ionophore / propionate / sheep

\section{INTRODUCTION}

Feeding may affect glucose metabolism in ruminants fed once or twice daily, because some researchers have shown changes in plasma glucose and insulin concentrations by feeding $[1,2]$. However, previous reports have shown that whole body glucose entry and/or utilization rates were enhanced by feeding in cattle fed a 30\% concentrate diet [1], but were not in sheep fed hay alone $[3,4]$. These previous results

\footnotetext{
*Corresponding author: sano@iwate-u.ac.jp
}

suggest that the effect of feeding on whole body glucose metabolism may be greater when the percentage of concentrate in a diet is higher.

Ionophores, which include monensin, lasalocid and salinomycin (SL), improve feed efficiency [5-7], increase propionate percentage [5-7] and propionate production $[8,9]$ in the rumen and enhance whole body glucose production [10]. Similar to the effect of feeding, the effect of ionophore supplementation on whole body glucose metabolism may be greater 
when ruminants are given a higher amount of concentrate, because monensin supplementation results in greater increases in ruminal propionate percentage $[11,12]$, ruminal propionate production and whole body glucose entry and irreversible loss rates [13] in cattle fed diets having higher percentages of concentrate.

In view of these previous results, feeding and ionophore supplementation are expected to enhance additively or interactively whole body glucose metabolism when ruminants are fed a high-concentrate diet once or twice daily. However, it is unknown whether ionophore supplementation modifies the response of glucose metabolism to feeding in ruminants.

The present study was designed to investigate the effects of feeding and SL on whole body glucose entry and utilization rates, and concentrations of plasma insulin and blood volatile fatty acids (VFA) in sheep fed a high-concentrate diet once daily.

\section{MATERIALS AND METHODS}

\subsection{Animals and management}

Four adult Corriedale wethers (2 y age, BW $50.7 \pm 5.7 \mathrm{~kg}$; mean \pm SEM) were surgically prepared under anesthesia with a skin loop enclosing the left carotid artery. Two of the sheep also had an established rumen fistula. Animals were kept individually in metabolic cages at room temperature. An experimental diet consisted of $250 \mathrm{~g} \cdot \mathrm{kg}^{-1}$ of orchardgrass hay (moisture 76 , crude protein 169 , ether extract 21 , neutral detergent fiber 407 , crude ash 90 , nitrogen-free extract $388 \mathrm{~g} \cdot \mathrm{kg}^{-1}$, metabolizable energy (ME) $1.92 \mathrm{Mcal} \cdot \mathrm{kg}^{-1}$ ) and $750 \mathrm{~g} \cdot \mathrm{kg}^{-1}$ of a commercial concentrate (Blue, Showa Sangyo Co., Japan; moisture 112 , crude protein 163 , ether extract 28 , neutral detergent fiber 325 , crude ash 64, nitrogen-free extract $572 \mathrm{~g} \cdot \mathrm{kg}^{-1}$, ME $\left.2.43 \mathrm{Mcal} \cdot \mathrm{kg}^{-1}\right)$. Salinomycin $\left(20 \mathrm{mg} \cdot \mathrm{kg}^{-1}\right.$ diet) was supplemented to the diet by mixing into the concentrate. Two sheep (one with and the other without the rumen fistula) were fed the diet with SL and the others without SL for $3 \mathrm{wk}$, and then SL treatment was switched and continued for 3 wk. Both diets were fed at equal ME (1.3 times requirement for maintenance) [14], once daily at 16:00 h. Water and mineral blocks were available ad libitum. Surgery, management, and blood sampling were carried out according to the guidelines established by the Animal Care Committee of Iwate University.

\subsection{Blood metabolites and insulin, and ruminal characteristics}

The responses of blood VFA, plasma glucose and insulin to feeding were examined on day 14 of each treatment. A catheter for blood sampling was inserted into the skin loop of the carotid artery at $2 \mathrm{~h}$ before the experiments, and was flushed and filled with a sterile solution of trisodium citrate $\left(38 \mathrm{~g} \cdot \mathrm{L}^{-1}\right)$. Blood samples $(5 \mathrm{~mL})$ for glucose and insulin determinations were obtained from the arterial catheter immediately before $(0 \mathrm{~min})$ and at $5,10,15,30,45,60,90,120$ and $180 \mathrm{~min}$ after feeding. Additional blood samples $(5 \mathrm{~mL})$ were taken for VFA determination at $0,30,60,90,120$ and $180 \mathrm{~min}$ after feeding. The samples were heparinized immediately and stored in crushed ice until centrifugation or deproteinization. Plasma was separated from the blood by centrifugation at $8000 \mathrm{~g}$ for $10 \mathrm{~min}$ at $4{ }^{\circ} \mathrm{C}$, and stored at $-20{ }^{\circ} \mathrm{C}$ until analysis of glucose and insulin concentrations. For VFA determination, $5 \mathrm{~mL}$ of blood were deproteinized by adding $5 \mathrm{~mL}$ of sodium tungstate solution $\left(100 \mathrm{~g} \cdot \mathrm{L}^{-1}\right)$ and $5 \mathrm{~mL}$ of $0.34 \mathrm{M} \mathrm{H}_{2} \mathrm{SO}_{4}$, and then the supernatants obtained were stored at $-20{ }^{\circ} \mathrm{C}$ until analysis.

In the two animals with the rumen fistula, rumen fluids $(50 \mathrm{~mL})$ were taken via 
the fistula immediately after blood sampling at $0,30,60,90,120$ and $180 \mathrm{~min}$ after feeding. The $\mathrm{pH}$ of the samples was measured immediately with a $\mathrm{pH}$ meter (HM-10P, Toa Electronics Ltd., Japan) and then stored at $4{ }^{\circ} \mathrm{C}$ after adding a few drops of saturated $\mathrm{HgCl}_{2}$ solution. The samples were centrifuged at $700 \mathrm{~g}$ for $15 \mathrm{~min}$ at $4{ }^{\circ} \mathrm{C}$, and then the supernatants were stored at $-20{ }^{\circ} \mathrm{C}$ until VFA analysis.

\subsection{Glucose kinetics}

On day 16 of each treatment, the response of whole body glucose kinetics to feeding was examined using a stableisotope dilution technique. A catheter for infusion was inserted into a jugular vein the day before the experiments, and another catheter for blood sampling was inserted into the skin loop of the carotid artery at $2 \mathrm{~h}$ before the experiments. The catheters were flushed and filled with a sterile solution of trisodium citrate $\left(38 \mathrm{~g} . \mathrm{L}^{-1}\right) \cdot\left[{ }^{13} \mathrm{C}_{6}\right]$ Glucose (D-glucose${ }^{13} \mathrm{C}_{6}, 99$ atm $\%{ }^{13} \mathrm{C}$, Isotec Inc., USA) dissolved in a sterile saline $\left(9 \mathrm{~g} \cdot \mathrm{L}^{-1}\right.$ sodium chloride solution) was injected as a priming dose of $300 \mu \mathrm{g} \cdot \mathrm{kg}^{-1} \mathrm{BW}$ over $1 \mathrm{~min}$ via the jugular catheter at $5 \mathrm{~h}$ before feeding, and then it was continuously infused at a rate of $3 \mu \mathrm{g} \cdot \mathrm{kg}^{-1} \mathrm{BW} \cdot \mathrm{min}^{-1}$ over $8 \mathrm{~h}$ via the same catheter using a peristaltic pump (AC-2120, Atto Co. Ltd., Japan). Blood samples $(5 \mathrm{~mL})$ were obtained from the arterial catheter before infusion (a background sample) and at 30-min intervals from 3 through $8 \mathrm{~h}$ after the initiation of infusion (from $2 \mathrm{~h}$ before through $3 \mathrm{~h}$ after feeding). The samples were heparinized immediately and stored in crushed ice until centrifugation. The animals were fed immediately after the blood sampling at $5 \mathrm{~h}$ after the initiation of infusion. Plasma was separated from the blood by centrifugation at $8000 \mathrm{~g}$ for $10 \mathrm{~min}$ at $4{ }^{\circ} \mathrm{C}$, and stored at $-20{ }^{\circ} \mathrm{C}$ until analysis of $\left[{ }^{13} \mathrm{C}_{6}\right]$ glucose enrichment.

\subsection{Analysis}

Plasma glucose concentration was determined by a glucose oxidase method [15]. Plasma insulin concentration was assayed with a kit based on a double antibody RIA method (IRI 'Eiken', Eiken Chemical, Japan). Blood VFA concentrations were determined by GC (Model 5890, Hewlett-Packard Co., USA) after extraction from the supernatants, which were obtained from the deproteinization described above, by steam distillation [16]. Total VFA concentration in rumen fluid was determined by titrating a distillate from steam distillation with $0.1 \mathrm{M} \mathrm{NaOH}$. The titrated distillate was dried, and then its molar percentages of individual VFA were measured by GC.

Plasma $\quad\left[{ }^{13} \mathrm{C}_{6}\right]$ glucose enrichment (mol\% excess) was measured by the method described by Tserng and Kalhan [17] with the following modifications. Plasma $(0.5 \mathrm{~mL})$ was deproteinized by mixing with $1.5 \mathrm{~mL}$ of sulfosalicylic acid solution $\left(30 \mathrm{~g} \cdot \mathrm{L}^{-1}\right)$. The supernatant obtained was applied to a tandem column consisting of $0.5 \mathrm{~mL}$ cation exchange resin (Dowex 50W $\times 8$, hydrogen form) and $1 \mathrm{~mL}$ anion exchange resin (Dowex $1 \times 8$, acetate form), and then the column was washed with distilled water $(4 \times 1 \mathrm{~mL})$. The resulting eluent was evaporated to dryness at $100{ }^{\circ} \mathrm{C}$ under a stream of dry air, and then glucose in the dried residue was derivatized as described by Tserng and Kalhan [17]. The enrichment of $\left[{ }^{13} \mathrm{C}_{6}\right]$ glucose was determined by an electron impact ionization-selective ion monitoring method with a gas chromatograph-mass spectrometer (G-3000 gas chromatographM-2000 mass spectrometer, Hitachi Ltd., Japan). Ions $\mathrm{m} / \mathrm{z} 328$ (natural glucose; $\mathrm{M})$ and $334\left(\left[{ }^{13} \mathrm{C}_{6}\right]\right.$ glucose; $\left.\mathrm{M}+6\right)$ were monitored, and enrichment ([M+6] / $[\mathrm{M}+\mathrm{M}+6] \times 100)$ was obtained; the enrichment allows the determination of 
total glucose entry rate (total absorption, gluconeogenesis and glycogenolysis) and glucose irreversible loss rate, because $\mathrm{M}+6$ glucose is little recycled when $\left[{ }^{13} \mathrm{C}_{6}\right]$ glucose is infused as a tracer [18]. Standard solutions of known enrichments, ranging from 0.025 to $0.500 \mathrm{~mol} \%$ excess, were analyzed every time.

\subsection{Calculations}

Because the time intervals in sampling during $1 \mathrm{~h}$ after feeding were different between ruminal characteristics, concentrations of plasma glucose, insulin and blood VFA, these measurements were standardized to time intervals similar to those of the glucose kinetics. The standardization was conducted by dividing the areas under the curves of these measurements by time intervals every $0.5 \mathrm{~h}$ from 0 through $2 \mathrm{~h}$ after feeding or every $1 \mathrm{~h}$ from 2 through $3 \mathrm{~h}$ after feeding. Thus, the calculated values had the same units as the original measurements, and were used as data in figures shown in the results section and for statistical analysis.

Glucose turnover rate was calculated during the prefeeding period, which was considered to be a steady state, as follows [17]:

$$
I \times\left(E_{\mathrm{i}} / E_{\mathrm{p}}-1\right)
$$

where $I$ is the infusion rate of $\left[{ }^{13} \mathrm{C}_{6}\right]$ glucose $\quad\left(\mathrm{mg} \cdot \mathrm{kg}^{-1} \quad \mathrm{BW} \cdot \mathrm{min}^{-1}\right)$, and $E_{\mathrm{i}}$ and $E_{\mathrm{p}}$ are the enrichments of $\left[{ }^{13} \mathrm{C}_{6}\right]$ glucose in the tracer solution and plasma (mol\% excess), respectively. During the postfeeding period, the rates of entry $\left(R_{\mathrm{e}}\right)$ and utilization $\left(R_{\mathrm{u}}\right)$ of glucose were calculated separately every $0.5 \mathrm{~h}$ using non-steady state equations [19].

$$
\begin{gathered}
R_{\mathrm{e}}=\left(I-p \times V \times\left(\left(C_{1}+C_{2}\right) / 2\right) \times\left(\left(E_{2}-E_{1}\right) /\right.\right. \\
\left.\left.\quad\left(T_{2}-T_{1}\right) / 100\right)\right) \times\left(2 \times E_{\mathrm{i}} /\left(E_{2}+E_{1}\right)-1\right) \\
R_{\mathrm{u}}=R_{\mathrm{e}}-p \times V \times\left(\left(C_{2}-C_{1}\right) /\left(T_{2}-T_{1}\right)\right)
\end{gathered}
$$

where $C_{1}$ and $C_{2}$ are plasma glucose concentrations (mg.mL $\mathrm{mL}^{-1}$ ), and $E_{1}$ and $E_{2}$ are the enrichments of plasma $\left[{ }^{13} \mathrm{C}_{6}\right]$ glucose (mol\% excess) at time $T_{1}$ and $T_{2}$ (min), respectively. $V$ is the glucose distribution volume and $p$ is the pool fraction, and the respective values were assumed to be $179 \mathrm{~mL} \cdot \mathrm{kg}^{-1} \mathrm{BW}$ and 0.85 [20].

\subsection{Statistical analysis}

Statistical analysis was conducted using the MIXED procedure of SAS [21]. The data for ME intake were analyzed by a randomized block design with the animals as blocks. The data for ruminal characteristics, blood and plasma components, and the rates of glucose entry and utilization were analyzed by a split-plot design with repeated measures for the time after feeding. The main plot was SL treatment, sub plots were the time after feeding and an interaction between SL treatment and the time after feeding (SL $\times$ feeding interaction), and blocks was the animals. An autoregressive one order was used as a covariance structure for repeated measures. A comparison between entry and utilization rates of glucose at each time after feeding was carried out using a two-way analysis of variance with blocks as the animals. The difference in least squares means with Tukey adjustment was used to compare between levels in the main effects. The results were considered to be significant at $P<$ 0.10

\section{RESULTS}

Salinomycin did not affect ME intake (50.7 without SL vs. 50.3 with SL, SEM $0.1 \mathrm{kcal} \cdot \mathrm{kg}^{-1} \mathrm{BW}, P=0.22$, data not shown).

Salinomycin did not affect $\mathrm{pH}(P=$ 0.62 , Fig. 1$)$, total VFA concentration $(P=$ $0.80)$ or percentages of acetate $(P=0.37)$ or butyrate $(P=0.41)$ in rumen fluid, but numerically increased ruminal propionate percentage by $50 \%$ (22.2 without SL vs. 

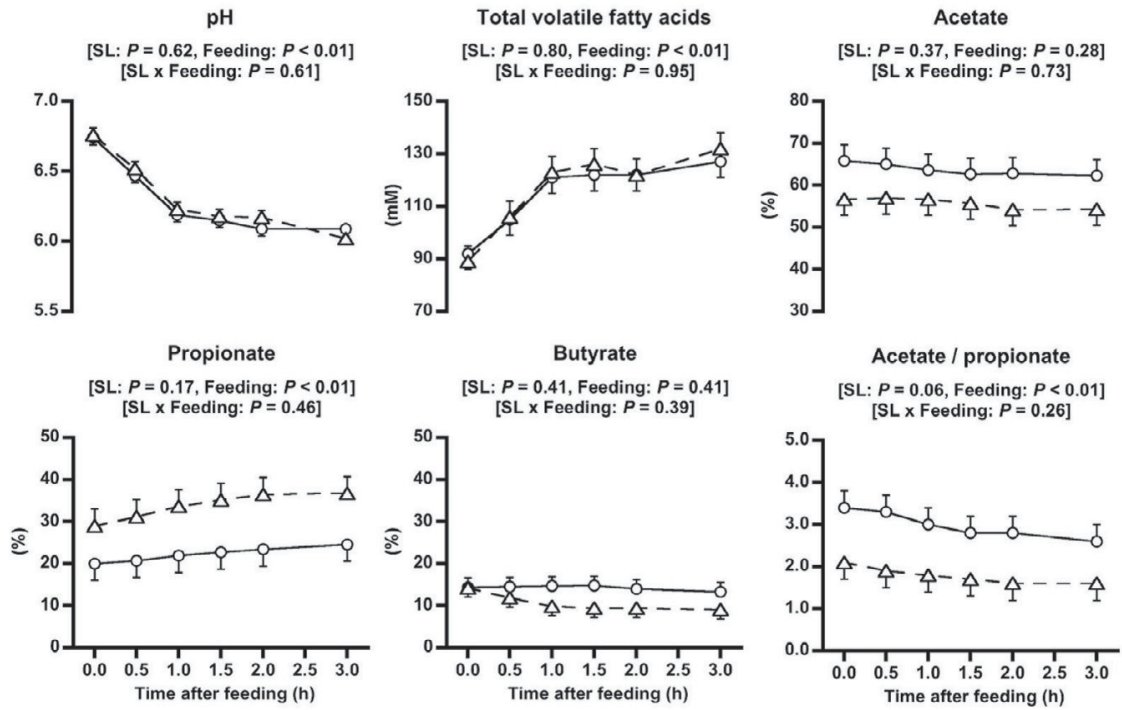

Figure 1. Salinomycin (SL) modifications on responses of ruminal characteristics to feeding in sheep fed a high-concentrate diet. o: without SL, $\Delta$ : with $20 \mathrm{mg} \cdot \mathrm{kg}^{-1}$ diet of SL. Data represent means and SEM of two sheep. $P$-values of the main effects of SL, the time after feeding (Feeding) and an interaction between SL and the time after feeding (SL $\times$ Feeding) are shown in brackets.

33.7 with SL, SEM $4.0 \%, P=0.17)$. The ratio of acetate to propionate in rumen fluid was decreased with SL (3.0 without SL vs. 1.7 with SL, SE 0.4, $P=0.06)$. Feeding affected $\mathrm{pH}(P<0.01)$, total VFA concentration $(P<0.01)$, propionate percentage $(P=0.01)$ and the ratio of acetate to propionate $(P<0.01)$. However, no SL $\times$ feeding interaction was found on any ruminal characteristics $(P \geq 0.10)$.

Salinomycin did not affect blood concentrations of acetate $(P=0.25$, Fig. 2) or butyrate $(P=0.95)$, but numerically increased that of propionate by $50 \%$ (24 without SL vs. 36 with SL, SEM $5 \mu \mathrm{M}$, $P=0.13)$. Blood acetate $(P<0.01)$ and propionate $(P=0.01)$ concentrations were affected by feeding. Blood acetate concentrations both with and without SL showed gradual increases from before through $3 \mathrm{~h}$ after feeding (from 312 to 576 , SEM $27 \mu \mathrm{M}$ ), whereas blood propionate concentrations were increased from before through $1 \mathrm{~h}$ after feeding (from 20 to 33 , SEM $5 \mu \mathrm{M}$ ) and then remained unchanged. Blood butyrate concentration was not affected $(P=0.46)$ by feeding. No SL $\times$ feeding interaction was found $(P \geq 0.10)$ on blood VFA concentrations.

Salinomycin did not affect plasma glucose concentration ( $P \geq 0.31$, Fig. 3), but numerically increased plasma insulin concentration (12.5 without SL vs. 16.9 with SL, SEM $2.2 \mu \mathrm{U} \cdot \mathrm{mL}^{-1}, P=0.12$ ). Feeding changed plasma glucose concentration $(P<0.01)$ : the concentration was lower for 1 to $2 \mathrm{~h}$ after feeding (63.7 to 64.7, SEM $2.3 \mathrm{mg} \cdot \mathrm{dL}^{-1}$ ) than at prefeeding $\left(68.6 \mathrm{mg} \cdot \mathrm{dL}^{-1}\right)$, but returned to the value close to prefeeding at $3 \mathrm{~h}$ after feeding. Plasma insulin concentration was also affected by feeding $(P=0.05)$ : the concentration increased from before to $0.5 \mathrm{~h}$ after feeding (from 12.1 to 17.0, SEM $2.3 \mu \mathrm{U} \cdot \mathrm{mL}^{-1}$ ) and thereafter gradually decreased toward the prefeeding value. No 

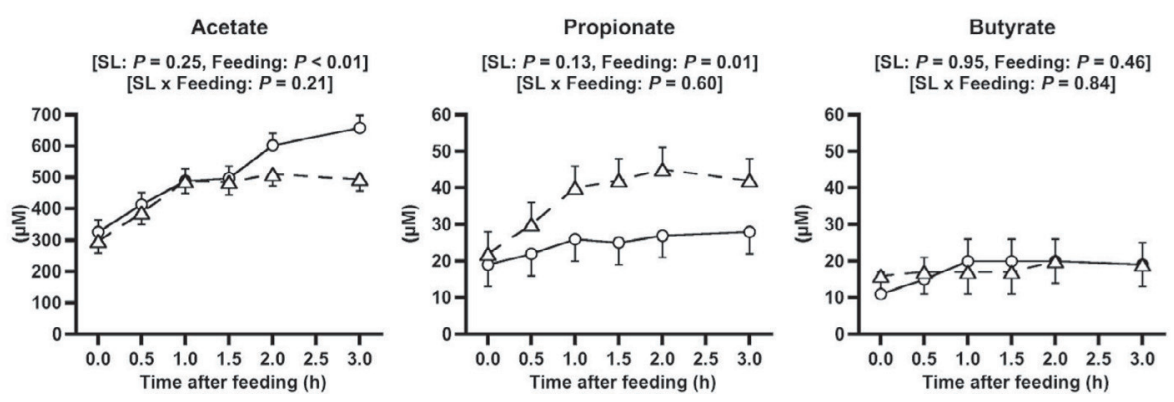

Figure 2. Salinomycin (SL) modifications on responses of blood volatile fatty acids concentrations to feeding in sheep fed a high-concentrate diet. o: without SL, $\Delta$ : with $20 \mathrm{mg} \cdot \mathrm{kg}^{-1}$ diet of SL. Data represent means and SEM of four animals. $P$-values of the main effects of SL, the time after feeding (Feeding) and an interaction between SL and the time after feeding (SL $\times$ Feeding) are shown in brackets.

\section{Glucose}

[SL: $P=0.31$, Feeding: $P<0.01]$

[SL x Feeding: $P=0.53$ ]

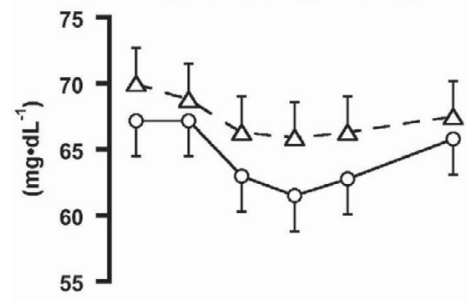

Glucose entry rate

[SL: $\boldsymbol{P}=0.01$, Feeding: $\boldsymbol{P}<0.01$ ]

[SL x Feeding: $P=0.21$ ]

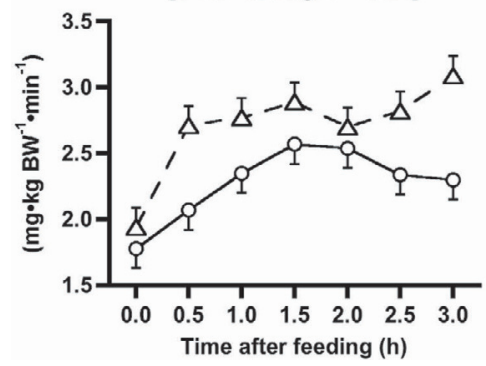

Insulin

[SL: $P=0.12$, Feeding: $P=0.05]$

[SL $\times$ Feeding: $P=0.66$ ]

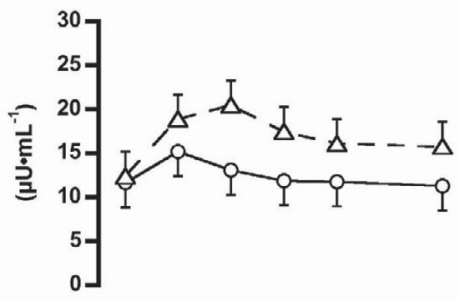

Glucose utilization rate

[SL: $P=0.01$, Feeding: $P<0.01$ ] [SL $x$ Feeding: $P=0.22$ ]

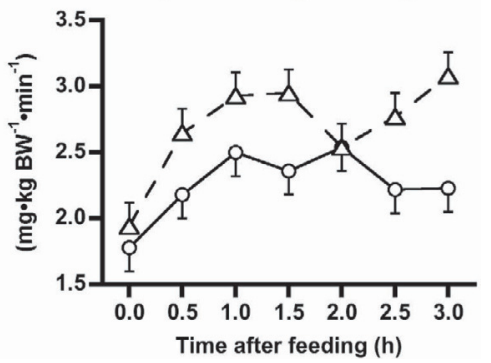

Figure 3. Salinomycin (SL) modifications on responses of plasma glucose and insulin concentrations, and the rates of entry and utilization of glucose to feeding in sheep fed a high-concentrate diet. $\circ$ : without SL, $\triangle$ : with $20 \mathrm{mg} \cdot \mathrm{kg}^{-1}$ diet of SL. Data represents means and SEM of four animals. $P$ values of the main effects of SL, the time after feeding (Feeding) and an interaction between SL and the time after feeding (SL $\times$ Feeding) are shown in brackets. 
significant $\mathrm{SL} \times$ feeding interaction was observed on plasma concentrations of glucose $(P=0.53)$ or insulin $(P=0.66)$.

Plasma glucose concentration and enrichment were relatively constant during $2 \mathrm{~h}$ before feeding; there were below 7.5 and $6.7 \%$ of $\mathrm{CV}$ for the concentration and enrichment, respectively, and no linear time trends $(P \geq 0.10)$ for these variables in any animals with or without SL (data not shown). Salinomycin increased the rates of glucose entry and utilization: the rates were 2.28 without SL vs. $2.70 \mathrm{mg} \cdot \mathrm{kg}^{-1} \mathrm{BW} \cdot \mathrm{min}^{-1}$ with SL for glucose entry (SEM $0.08 \mathrm{mg} \cdot \mathrm{kg}^{-1} \mathrm{BW} \cdot \mathrm{min}^{-1}$, $P=0.01$, Fig. 3), and 2.26 without SL vs. $2.69 \mathrm{mg} \cdot \mathrm{kg}^{-1} \mathrm{BW} \cdot \mathrm{min}^{-1}$ with SL for glucose utilization (SEM $0.09 \mathrm{mg} \cdot \mathrm{kg}^{-1}$ $\left.\mathrm{BW} \cdot \mathrm{min}^{-1}, P=0.01\right)$. Feeding also affected these rates $(P<0.01)$. The entry rate gradually increased from before through $1.5 \mathrm{~h}$ after feeding (from 1.86 to $2.73, \mathrm{SEM} 0.12 \mathrm{mg} \cdot \mathrm{kg}^{-1} \mathrm{BW} \cdot \mathrm{min}^{-1}$ ), and the utilization rate increased gradually from before through $1 \mathrm{~h}$ after feeding (from 1.86 to 2.71 , SEM $0.14 \mathrm{mg} \cdot \mathrm{kg}^{-1}$ $\left.\mathrm{BW} \cdot \mathrm{min}^{-1}\right)$. Thereafter, each rate maintained the increased values. The entry rate was similar to the utilization rate at each time after feeding in each SL treatment $(P \geq 0.10$, data not shown). No significant SL $\times$ feeding interaction was found on rates of glucose entry $(P=0.21)$ or utilization $(P=0.22)$.

\section{DISCUSSION}

In view of the present results for ruminal characteristics, we consider the SL effects on rumen metabolism to be typical of those found in ruminants fed a high-concentrate diet; however, the results have to be carefully interpreted because of the very small number of animals used. We chose to include this because we feel they indicate that sheep did receive SL and there were $\mathrm{SL}$ responses in the rumen. The decreased ratio of acetate to propionate with SL, which was due to the unchanged acetate percentage and the numerically increased propionate percentage, is similar to the results in SL supplemented cattle fed a $90 \%$ concentrate diet [22]. In contrast, Merchen and Berger [6] have reported an increased propionate percentage and a decrease in acetate percentage and a decreased ratio of acetate to propionate with SL in sheep fed a $60 \%$ concentrate diet. A lack of changes in ruminal $\mathrm{pH}$ and total VFA concentration with SL was also shown in these studies $[6,22]$.

We can more reliably interpret the results for concentrations of blood VFA, plasma glucose and insulin, and the rate of glucose entry and utilization than those for ruminal characteristics, because the data were obtained from four animals. The lack of any effects of SL, or any interactions between SL and feeding in blood acetate and butyrate concentrations suggests that SL does not modify the changes in availability and metabolism of these VFA with time after feeding a high-concentrate diet. However, the numerical increase in blood propionate concentration with SL may indicate an increase in propionate availability. Other researchers have shown an increase in propionate production with monensin in steers fed diets having various ratios of roughage to concentrate $[8,9,13]$.

Feeding increased blood concentrations of acetate and propionate, suggesting increases in acetate and propionate availability by feeding. The present results were similar to the results of Sano et al. [2], who have shown that blood concentrations of acetate and propionate during a $4 \mathrm{~h}$ postfeeding period were increased by feeding but not by SL supplementation in sheep fed a $75 \%$ alfalfa hay diet once daily.

In order to evaluate glucose kinetics under the condition where concentration and specific radioactivity (or enrichment) of glucose were varying, glucose kinetics during the postfeeding period were calculated 
by non-steady state equations [19]. These equations are based on one-compartment model with a glucose distribution volume $(V)$ and a pool fraction $(p)$, the product of $V$ and $p$ are presumed as a fraction of the glucose pool contributing to a rapid change in glucose metabolism [23]. The fixed values of both parameters [20] were assumed in the present study. However, $V$ may change with feeding, because it, derived from pool size and plasma concentration of glucose, has been lower by $26 \%$ during 2 to $4 \mathrm{~h}$ after feeding than during $2 \mathrm{~h}$ before feeding in sheep [4]. Salinomycin also possibly affects $V$, because Alieri et al. [10] have reported a 30\% increase in $V$ with monensin in Holstein cows. In contrast, derived from the results of Van Mannen et al. [13], $V$ showed only a 5\% increase with monensin in Holstein steers. However, considering changes in plasma glucose and insulin concentrations in the present study and the changes in $V$ with feeding and monensin in the previous studies, we suppose that a possible change in $V$ would not cause serious error in glucose entry and utilization rates in the present study. Indeed, in the present data, $30 \%$ changes in $V$ produced only less than $6 \%$ changes in both glucose entry and utilization rates depending on changes in concentration and enrichment of glucose.

The $p$ is the rapid-mixing fraction of the single compartment, which is based on the postulation that new glucose entering plasma mixes with only a constant fraction [23], and it is controversial in the non-steady state kinetic model. Because $p$ varies with time under nonsteady state conditions [24-26] and may differ between animal species [27] and between conditions being studied, glucose entry and utilization rates are probably subjected to some errors in the present experiment in which the fixed $p(0.85)$ was used. However, we suppose that the probable errors would not be large, since changes in plasma glucose (decrease by
$5 \mathrm{mg} \cdot \mathrm{dL}^{-1}$ ) and plasma insulin (increase by $8 \mu \mathrm{U} \cdot \mathrm{mL}^{-1}$ ) were not great. Previous studies have shown that errors in an onecompartment model with a fixed $p$ were large when the tracer-to-tracee ratio (i.e. specific activity or enrichment) was greatly varied by large changes in glucose and/or insulin concentrations with glucose infusion in dogs [28] and with glucose plus insulin infusion [24] and meal ingestion [26] in humans; an increase or decrease in the ratio would cause to underestimate or to overestimate, respectively, both glucose entry and utilization rates [24]. The errors can be minimized if a constant tracer-totracee ratio is held by the tracer infusion varied to mimic the anticipated pattern of change in glucose entry [24, 26, 28].

The response patterns of plasma concentrations of glucose and insulin to feeding are similar to previous results $[1,2]$. The responses of rates of glucose entry and utilization to feeding in the present study suggest that feeding would enhance both glucose entry and utilization rates in sheep fed a high-concentrate diet once daily. These results are similar to the results indicated by Armentano et al. [1] in Holstein steers fed a diet containing 70\% hay and 30\% cracked corn twice daily. They infused $\left[\mathrm{U}_{-}{ }^{14} \mathrm{C}\right]$ glucose for $30 \mathrm{~h}$ into steers and showed a sinusoidal response to feeding in plasma glucose specific radioactivity with a cyclic period of $12 \mathrm{~h}$ and a maximum value at feeding time; this finding suggests that feeding enhances glucose metabolism. In contrast, other researchers have reported little change in glucose turnover rate with time after feeding in sheep fed hay alone once [3] or twice daily [4]. In view of the present and these previous results, the response to feeding in rates of glucose entry and utilization may be influenced by the content of concentrate in a diet, which may be associated with enhanced propionate availability and insulin secretion after feeding due to more rapid fermentation of starch than of fibre. 
Considering different sensitivities to insulin between glucose production and utilization, it may be strange that plasma insulin concentration, glucose entry and utilization rates increased similarly and simultaneously during the postfeeding period. Endogenous glucose production was suppressed by 30 to $60 \%$ and glucose utilization was stimulated by 0 to $30 \%$ when plasma insulin concentration was increased to twofold that of basal states by insulin infusion with a maintained plasma glucose concentration [29-31]. This suggests that the increase in plasma insulin concentration during the postfeeding period in the present study should produce a decrease in glucose entry and no change or a slight increase in glucose utilization. Because gluconeogenesis from propionate is poorly suppressed with insulin [32], an increase in propionate absorption may contribute to the increased glucose entry rate, as suggested by increased plasma propionate concentration with feeding, especially in SL treatment. This may be supported by a report showing that the propionate release from the stomach and portal drained viscera increased during 0.5 to $3.5 \mathrm{~h}$ after feeding in beef steers receiving lucerne hay twice daily, although it remained unchanged in those receiving a pelleted concentrate because of a high value at prefeeding [33]. In addition, an increase in glucose absorption may contribute to the increased glucose entry rate during the latter half of the postfeeding period, because Reynolds and Huntington [34] have reported increases in glucose release from mesenteric- and portal-drained viscera during 1.5 to $3.5 \mathrm{~h}$ after feeding in beef steers receiving a pelleted concentrate twice daily.

The extent of increase in glucose utilization after feeding appears to be so great that the increase may not be solely associated with the increased plasma insulin concentration; the increase may involve an increase in insulin-independent glucose utilization and/or an enhancement in insulin sensitivity of insulin-sensitive tissues. Even though a feeding-induced change in glucose utilization has not been well investigated in tissues of ruminants, the gastrointestinal tract, whose activity is increased with feeding and whose glucose utilization is insulin-independent $[35,36]$, does not appear to significantly contribute to the possible increase in insulin-independent glucose utilization. This is because glucose uptake of neither the stomach or mesenteric-drained viscera did not change greatly during 0.5 to $3.5 \mathrm{~h}$ after feeding when steers were given a pelleted concentrate twice daily [34].

Recently, there have been interesting reports that suppose that insulin sensitivity of insulin-sensitive tissues may be enhanced during the early period after feeding. In mice, ghrelin, which is released mainly from the oxyntic gland of the stomach with a transient surge just before feeding and stimulates $\mathrm{GH}$ secretion in rodents and ruminants [37], attenuates the capacity of insulin to suppress endogenous glucose production but reinforces that which stimulates glucose disposal, when it is infused for $3 \mathrm{~h}$ [38]. However, the steady-state glucose infusion rate was unaffected by ghrelin infusion in a hyperinsulinemic euglycemic clamp experiment in sheep [39]. It may be necessary to investigate whether a transient surge just before feeding in ghrelin produces a change in insulin sensitivity for glucose utilization rate in ruminants, in order to elucidate a mechanism for producing the feeding-induced increase in the rate.

We had expected that SL would affect glucose kinetics more greatly after feeding than before feeding via an enhancement in insulin secretory response, because some researchers have shown that SL enhanced insulin secretory responses to feeding [40] and to glucose injection [41] in sheep. However, SL $\times$ feeding interactions were not observed on plasma concentrations of 
glucose or insulin, or the rates of glucose entry or utilization in the present study, although SL, as discussed below, and feeding each increased these rates. The present results suggest that the combined effect of SL and feeding on glucose kinetics is additive, but not interactive, in sheep fed a high-concentrate diet.

The responses of glucose kinetics and concentrations of plasma glucose and insulin to SL supplementation suggest that SL would increase both glucose entry and utilization rates without greatly changing peripheral plasma concentrations of glucose and insulin. The numerical increase in plasma insulin concentration with SL shows the possibility that SL may increase insulin secretion. Terashima et al. [40] have also shown an increase in the area under the curve of plasma insulin concentration during a $6 \mathrm{~h}$ postfeeding period with SL in steers fed a high-roughage diet. In contrast, Sano et al. [2] reported a lack of change in plasma insulin area under the curve during a $4 \mathrm{~h}$ postfeeding period in sheep fed a high-roughage diet with SL.

Although there are no reports about the effects of dietary SL on whole body glucose kinetics in ruminants, the increased rates of glucose entry and utilization with SL are similar to the effects of monensin on glucose kinetics described by Van Maanen et al. [13], who have shown increases in the rates of entry and irreversible loss of glucose with monensin in steers fed a diet containing $20 \%$ alfalfa hay, $64 \%$ cracked corn and $16 \%$ protein supplement. The increased entry rate with SL may be partly attributed to an increase in propionate availability, as suggested by the numerical increase in blood propionate concentration. This may be supported by previous results that monensin has increased ruminal propionate production in ruminants $[8,9,13]$, although there is no research investigating the effects of dietary SL on ruminal propionate production. In addition, an increase in absorbed glucose may also con- tribute to the increased glucose entry rate with SL. Some previous results suggest that ionophore supplementation may increase glucose absorption: a decrease in the percentage of starch digested in the rumen and an increase in the amount of starch digested in the lower-digestive tract in steer supplemented with monensin [42] and in lamb supplemented with lasalocid [43], and a tendency for a decrease in glucose uptake of portal-drained viscera (this causes an increase in glucose entry into the portal vein) with monensin in steers fed alfalfa hay [44] or a high-grain diet [45].

The increased glucose utilization rate with SL may be partly associated with the numerical increase in plasma insulin concentration. Although enhancements in tissue sensitivity and responsiveness to insulin also result in an increase in glucose utilization $[3,20]$, the increase in glucose utilization rate with SL does not at least appear to be associated with the enhancement in responsiveness to insulin. This is because the tissue responsiveness to insulin evaluated by a glucose clamp technique has been unaffected by SL supplementation in sheep fed either a high-roughage or high-concentrate diet $[2,46]$. Considering these results, the major part of increment in glucose utilization with SL is supposed to be due to an insulin-independent mechanism. However, the mechanism is unclear as well as that of a possible increase in insulin-independent glucose utilization with feeding. Research may be needed for elucidating the mechanism, because insulin-independent glucose utilization accounts for over $80 \%$ of total glucose utilization in ruminants in a basal state [29].

In conclusion, SL and feeding would have an additive effect on the rates of glucose entry and utilization in sheep when a high-concentrate diet is fed. The additive effect would be absent on the peripheral concentrations of blood propionate and plasma insulin and glucose: feeding would influence these concentrations, but 
SL would not. Both SL- and feedinginduced increases in glucose entry rate are likely to be mainly responsible for increased propionate availability, and those in glucose utilization may be significantly attributed to an insulin-independent mechanism.

\section{ACKNOWLEDGEMENTS}

The authors are grateful to Mr. Kim Taylor for his kind comments on the manuscript.

\section{REFERENCES}

[1] Armentano LE, Mills SE, de Boer G, Young JW. Effects of feeding frequency on glucose concentration, glucose turnover, and insulin concentration in steers. J Dairy Sci 1984, 67: 1445-1451.

[2] Sano H, Terashima Y, Takahashi H. Effects of dietary salinomycin on postprandial changes in plasma insulin and glucagon concentrations, and insulin secretory response and action in sheep. Anim Sci Technol 1994, 65: 601-609.

[3] Sano H, Takebayashi A, Kodama Y, Nakamura $\mathrm{Y}$, Ito $\mathrm{H}$, Arino $\mathrm{Y}$, Fujita $\mathrm{T}$, Takahashi H, Ambo K. Effects of feed restriction and cold exposure on glucose metabolism in response to feeding and insulin in sheep. J Anim Sci 1999, 77: 2564-2573.

[4] Van der Walt JG. Volatile fatty acid metabolism in sheep. 3. Diurnal variation in the contribution of ruminal propionic acid production to the whole body glucose turnover of Merino sheep fed lucerne hay twice daily. Onderstepoort J Vet Res 1978, 45: 125-132.

[5] Bagley CP, Feazel JI, Morrison DG, Lucas DM. Effects of salinomycin on ruminal characteristics and performance of grazing beef steers. J Anim Sci 1988, 66: 792-797.

[6] Merchen NR, Berger LL. Effect of salinomycin level on nutrient digestibility and ruminal characteristics of sheep and feedlot performance of cattle. J Anim Sci 1985, 60: 1338-1346.

[7] Reffett-Stabel J, Spears JW, Harvey RW, Lucas DM. Salinomycin and lasalocid effects on growth rate, mineral metabolism and ruminal fermentation in steers. J Anim Sci 1989, 67: 2735-2742
[8] Prange RW, Davis CL, Clark JH. Propionate production in the rumen of Holstein steers fed either a control or monensin supplemented diet. J Anim Sci 1978, 46: 11201124.

[9] Rogers JA, Davis CL. Rumen volatile fatty acid production and nutrient utilization in steers fed a diet supplemented with sodium bicarbonate and monensin. J Dairy Sci 1982 , 65: 944-952.

[10] Arieli A, Vallimont JE, Aharoni Y, Varga GA. Monensin and growth hormone effects on glucose metabolism in the prepartum cow. J Dairy Sci 2001, 84: 2770-2776.

[11] Ramanzin M, Bailoni L, Schiavon S, Bittante G. Effect of monensin on milk production and efficiency of dairy cows fed two diets differing in forage to concentrate ratios. J Dairy Sci 1997, 80: 1136-1142.

[12] Zinn RA, Plascencia A, Barajas R. Interaction of forage level and monensin in diets for feedlot cattle on growth performance and digestive function. J Anim Sci 1994, 72: 2209-2215.

[13] Van Maanen RW, Herbein JH, McGilliard $\mathrm{AD}$, Young JW. Effects of monensin on in vivo rumen propionate production and blood glucose kinetics in cattle. J Nutr 1978, 108: 1002-1007.

[14] NRC. Nutrient Requirements of Sheep. 6th rev ed, Natl Acad Press, Washington, DC, 1985.

[15] Huggett AG, Nixon DA. Enzymic determination of blood glucose. Biochem J 1957, 66: $12 \mathrm{P}$.

[16] Sano H, Terashima Y, Senshu T. Insulin secretory response to feeding in sheep fed a diet supplemented with calcium, potassium and sodium propionate. Jpn J Zootech Sci 1989, 60: 70-77.

[17] Tserng K-Y, Kalhan SC. Estimation of glucose carbon recycling and glucose turnover with $\left[\mathrm{U}-{ }^{13}\right.$ C]glucose. Am J Physiol 1983, 245: E476-E482.

[18] Wolf RR. Isotope measurement of glucose and lactate kinetics. Ann Med 1990, 22: 163 170.

[19] Cowan JS, Hetenyi G Jr. Glucoregulatory responses in normal and diabetic dogs recorded by a new tracer method. Metabolism 1971, 20: 360-372.

[20] Weekes TEC, Sasaki Y, Tsuda T. Enhanced responsiveness to insulin in sheep exposed to cold. Am J Physiol 1983, 244: E335-E345.

[21] SAS. SAS/STAT ${ }^{\circledR}$ Software: Changes and Enhancements through Release 6.11. SAS Inst Inc, Cary, NC, 1996.

[22] Zinn RA. Influence of forage level on response of feedlot steers to salinomycin 
supplementation. J Anim Sci 1986, 63: 2005-2012.

[23] Steel R. Influence of glucose loading and of injected insulin on hepatic output. Ann NY Acad Sci 1959, 82: 420-430.

[24] Butler PC, Caumo A, Zerman A, O’Brien PC, Cobelli C, Rizza RA. Methods for assessment of the rate of onset and offset of insulin action during nonsteady state in humans. Am J Physiol 1993, 264: E548-E560.

[25] Livesey G, Wilson PDG, Danity JR, Brown JC, Faulks RM, Roe MA, Newman TA, Eagle J, Mellon FA, Greenwood RH. Simultaneous time-varying systemic appearance of oral and hepatic glucose in adults monitor with stable isotopes. Am J Physiol 1998, 275: E717-E728.

[26] Basu R, Camillo BD, Toffolo G, Basu A, Shah P, Vella A, Rizza R, Cobelli C. Use of a novel triple-tracer approach to assess postprandial glucose metabolism. Am J Physiol 2003, 284: E55-E69.

[27] Proietto J, Rohner-Jeanrenaud F, Ionescu E, Terrettas J, Sauter JF, Jeanrenaud B. Non-steady-state measurement of glucose turnover in rats by a one-compartment model. Am J Physiol 1987, 252: E77-E84.

[28] Radziuk J, Norwich KH, Vranic M. Experimental validation of measurements of glucose turnover in nonsteady state. Am J Physiol 1978, 234: E84-E93.

[29] Janes AN, Weekes TEC, Armsrtrong DG. Insulin action and glucose metabolism in sheep fed on dried-grass or ground, maizebased diets. Br J Nutr 1985, 54: 459-471.

[30] Debras E, Grizard J, Aina E, Tesseraud S, Champredon C, Arnal M. Insulin sensitivity and responsiveness during and dry period in goats. Am J Physiol 1989, 256: E295-E302.

[31] Faulkner A, Pollock HT. Metabolic responses to euglycemic hyperinsulinaemia in lactating and non-lactating sheep in vivo. $\mathrm{J}$ Endocrinol 1990, 124: 59-66.

[32] Brockman RP. Effect of insulin on the utilization of propionate in gluconeogenesis in sheep. Br J Nutr 1990, 64: 95-101.

[33] Reynolds CK, Huntington GB. Partition of portal-drained visceral net flux in beef steers. 2 . Net flux of volatile fatty acids, D- $\beta$ hydroxybutyrate and L-lactate across stomach and post-stomach tissues. Br J Nutr 1988, 60: 553-562.

[34] Reynolds CK, Huntington GB. Partition of portal-drained visceral net flux in beef steers. 1. Blood flow and net flux of oxygen, glucose and nitrogenous compounds across stomach and post-stomach tissues. Br J Nutr 1988, 60: 539-551.
[35] Eisemann JH, Huntigton GB. Metabolite flux across portal-drained viscera, liver, and hindquarters of hyperinsulinemic, euglycemic beef steers. J Anim Sci 1994, 72: 2919-2929.

[36] Eisemann JH, Huntington GB, Catherman DR. Insulin sensitivity and responsiveness of portal-drained viscera, liver, hindquarters, and whole body of beef steers weighing 275 or $490 \mathrm{~kg}$. J Anim Sci 1997, 75: 2084-2091.

[37] Sugino T, Hasegawa Y, Kurose Y, Kojima M, Kanagawa K, Terashima Y. Effects of ghrelin on feed intake and neuroendocrine function in sheep. Anim Prod Sci 2004, 82-83: 183 194.

[38] Heijboer AC, van den Hoek AM, Parlevliet ET, Havekes LM, Romijn JA, Pijl H, Corssmit EPM. Ghrelin differentially affects hepatic and peripheral insulin sensitivity in mice. Diabetologia 2006, 49: 732-738.

[39] Takahashi H, Kurose Y, Kobayashi S, Sugino T, Kojima M, Kanagawa K, Hasegawa Y, Terashima Y. Ghrelin enhances glucoseinduced insulin secretion in scheduled mealfed sheep. J Endocrinol 2006, 189: 67-75.

[40] Terashima Y, Kuroyanagi T, Miyakoshi Y, Fukuda Y, Kondo Y. The effect of dietary salinomycin supplementation on insulin secretory response to feeding in fattening steers. Jpn J Zootech Sci 1990, 61: 271-276.

[41] Ambo K, Yoshida K, Nakashima Y. Effect of salinomycin supplementation on plasma glucose and insulin responses to intravenous injection of glucose in sheep. Asian-Aust J Anim Sci 1989, 2: 222-223.

[42] Muntifering RB, Theurer B, Noon TH. Effects of monensin on site and extent of whole corn digestion and bacterial protein synthesis in beef steers. J Anim Sci 1981, 53: 1565-1573.

[43] Funk MA, Galyean ML, Ross TT. Potassium and lasalocid effects on performance and digestion in lambs. J Anim Sci 1986, 63: 685-691.

[44] Harmon DL, Kreikemeier KK, Gross KL. Influence of addition of monensin to an alfalfa hay diet on net portal and hepatic nutrient flux in steers. J Anim Sci 1993, 71: 218-225.

[45] Harmon DL, Avery TB, Huntington GB, Reynolds PJ. Influence of ionophore addition to roughage and high-concentrate diets on portal blood flow and net nutrient flux in cattle. Can J Anim Sci 1988, 68: 419-429.

[46] Fujita T, Itoh T, Majima H, Sano H, Shiga A, Ambo K. Effects of type of diet and salinomycin supplementation on insulin secretory response and action in sheep. Anim Sci J 2000, 71: 42-49. 